\title{
Research Paper \\ Meta-Analysis of the Effectiveness of Interventions Based on Play Therapy on the Adaptive Behavior in Children with Intellectual Disability
}

\author{
Mohammad Ashori ${ }^{1}$, Ahmad Abedi ${ }^{* 2}$ \\ 1. Assistant Professor, Department of Psychology and Education of Children with Special Needs, Faculty of Education and \\ Psychology, University of Isfahan, Iran \\ 2. Associate Professor, Department of Psychology and Education of Children with Special Needs, Faculty of Education and \\ Psychology, University of Isfahan, Iran
}

Citation: Ashori M, Abedi A. Meta-analysis of the effectiveness of interventions based on play therapy on the adaptive behavior in children with intellectual disability. Quarterly Journal of Child Mental Health. 2020; 7(1): 93-105.

\section{http://dx.doi.org/10.29252/jcmh.7.1.9}

\section{A R T I C L E I N F O}

\section{Keywords:}

Meta-analysis,

play therapy, adaptive behavior, intellectual disability

Received: 1 Jul 2018

Accepted: 22 Oct 2018

Available: 23 May 2020

\section{A B S T R A C T}

Background and Purpose: One of the most important criteria for defining and identifying of intellectual disability is significant problems in adaptive behaviors. Since play is one of the ways to improve adaptive behavior in these children, it seems that conducting a meta-analysis will help determine the actual effect of play-based interventions on their adaptive behavior. Thus, the present study aimed to investigate the effectiveness of interventions based on play therapy on the adaptive behavior in children with intellectual disability in Iran.

Method: This research is a meta-analysis. Prior to analyzing the effect size of the mean differences, the PRISMA method was used to determine the decision tree model. Then, using the meta-analysis technique, the effect size of play-based interventions was determined. 10 of the 19 studies conducted in Iran with the keywords play, play therapy, adaptive behavior, mental retardation, and intellectual disability published at SID, IranMedex, IranDoc, Google Scholar, and Magiran during 2008-2018, were collected according to the entry and exit criteria and analyzed through meta-analysis. The research instrument was a meta-analysis checklist, and comprehensive meta-analysis (CMA) software was used to analyze the descriptive data and effect size of the research.

Results: Findings showed that the effect size of the difference between the meanings of play-based interventions on adaptive behavior was $0.65(\mathrm{P} \leq 0.00001)$, which is high according to Cohen's table (1998).

Conclusion: Given the high impact of play-based interventions, it can be said that this method of intervention can play a major role in improving the adaptive behavior of children with intellectual disability and can be used as an appropriate method in the rehabilitation of these children.

\footnotetext{
* Corresponding author: Ahmad Abedi, Associate Professor, Department of Psychology and Education of Children with Special Needs, Faculty of Education and Psychology, University of Isfahan, Iran.

E-mail addresses: A.abedi@edu.ui.ac.ir
}

2476-5740/ () 2019 The Authors. This is an open access article under the CC BY-NC-ND license (https://creativecommons.org/licenses/by-nc-nd/3.0/). 


\section{فراتحليل تأثير مداخلات مبتنى بر بازىدرمانى بر رفتار سازشى كود كان كمتوان ذهنى \\ r* محمد عاشورى' '، احمد عابدى

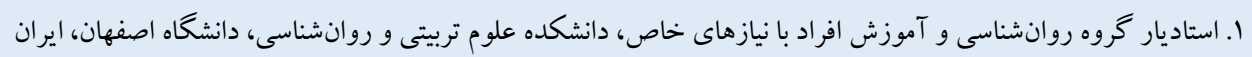

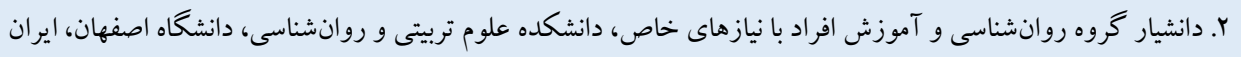

جكيده

زمينه و هدف: يكى از مهم ترين ملاككهاى تعريف و تشخيص كم توانى ذهنى، مشكلات معنادار در رفتارهاى سازشى است. از آن جايى

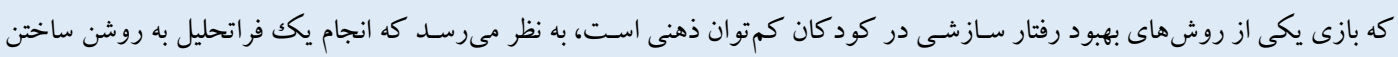

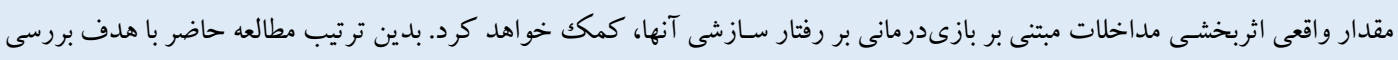

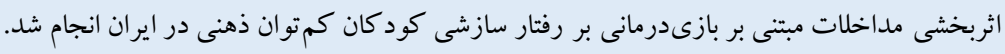

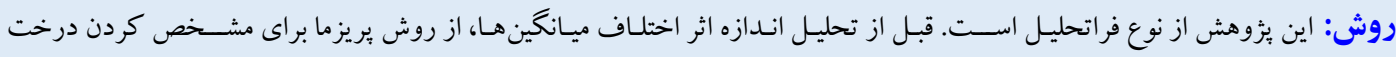

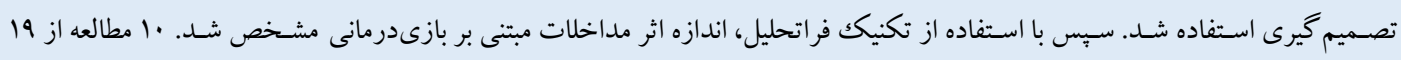

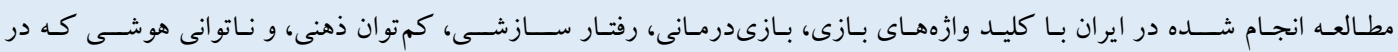

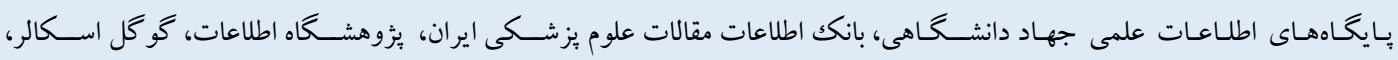

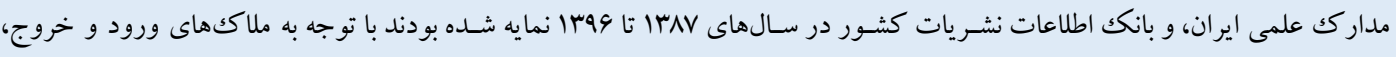

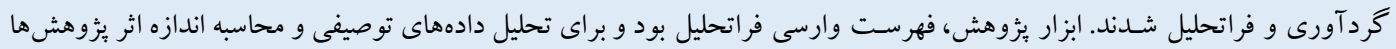

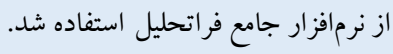

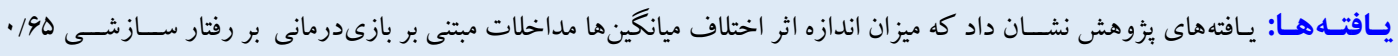

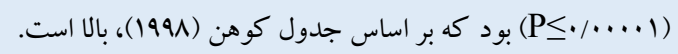

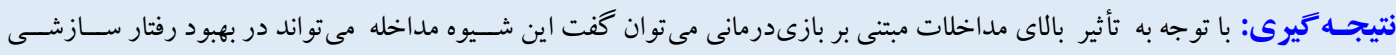

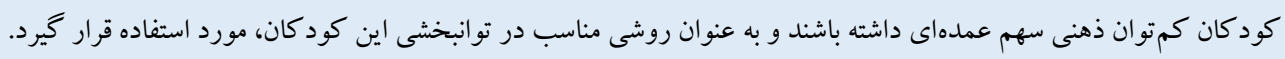

مشخصات مقاله

كليدوازهها:

فراتحليل،

بازى برمانى

رفتار سازشى،

كمتوانى ذهنى

دريافت شده: ·PV/F/

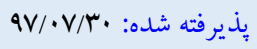

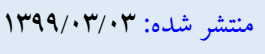

* نويسنده مسئول: احمد عابدى، دانشيار گروه روانشناسى و آموزش افراد با نيازهاى خاص، دانشكده علوم تربيتى و روانشناسى، دانشكاه اصفهان، ايران.

راياناه،: A.abedi@edu.ui.ac.ir

تلفن تماس: rVarabFA - ا.ب. 
هدايت گرى" "مهارت هاى مربوط به سلامت و ايمنى، مهارتهاى مربوط

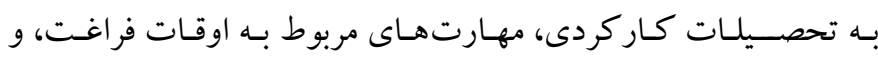

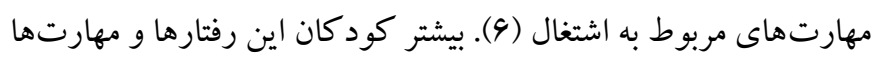

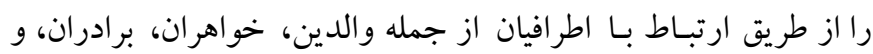

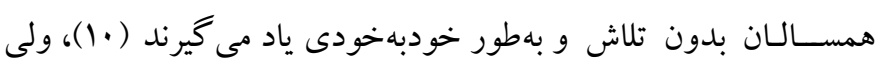

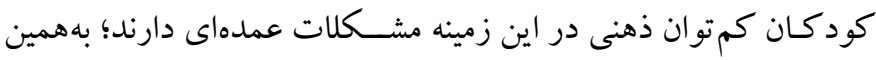

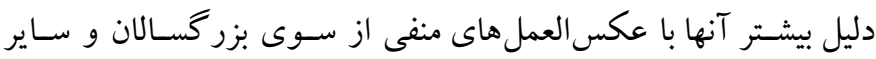

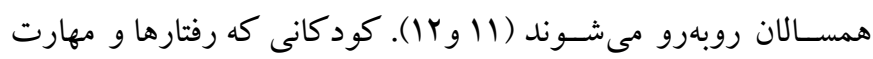
اجتماعى مطلوبى داشـته و مشـكلات رفتارى عمدهاى ندارند در ايجاد

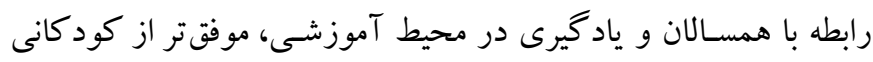

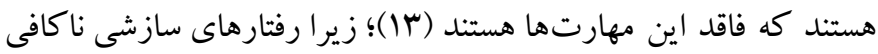
و مشكلات رفتارى عمده، سبب ايجاد روابط بين فردى ضعيف و تحول

$$
\text { اجتماعى نامطلوب مى شود (1) (I). }
$$

در حقيقـت، رفتارهاى ســازشنايافته كود كان كم توان ذهنى به نحو

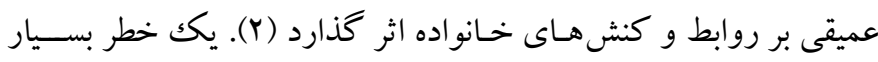
واقعى اين اسـت كه كود كان كمتوان ذهنى در مارييج تعامل هاى منفى روتى

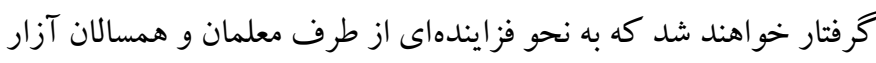

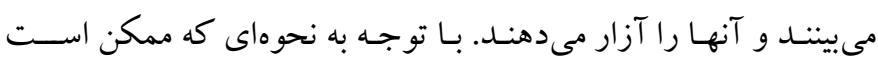

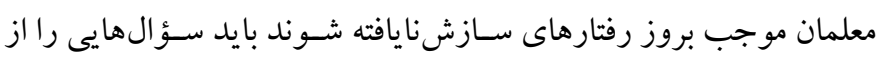

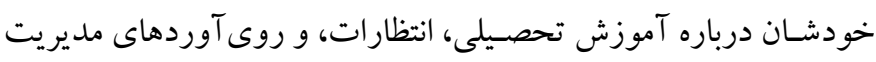
رفتار بيرســند. در نتيجه نبايد معلمان را براى رفتارهاى ســازشنايافته كه

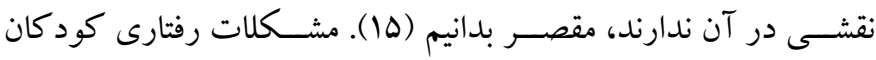
كم توان ذهنى به قدرى زياد اسـت كه افراد در حال تلاش براى دوستى بـ بال آنها، از اين كار دست برمىدارند (19).

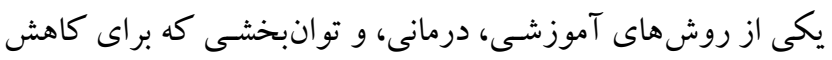

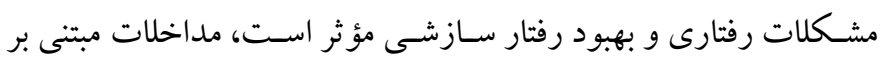

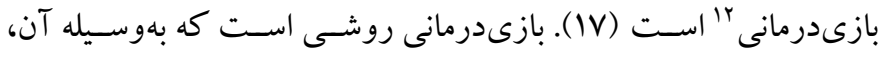

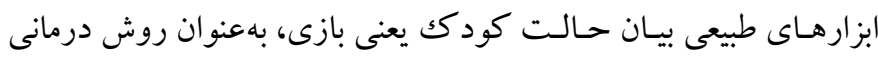

\section{Adaptive behavior}

9. Conceptual, social and practical

10. American Association of Mental Retardation

11. Self-direction

12. Play therapy
مقلدمه

در طول تاريخ از برجسبهاى مختلفى براى توصيف افرادى كه از نظر

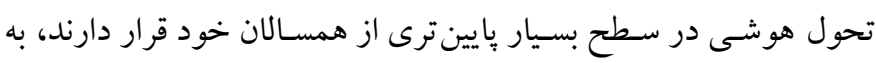

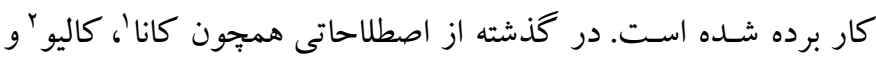

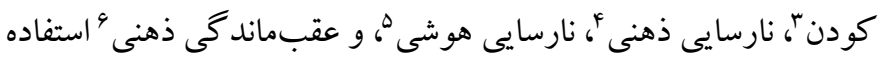

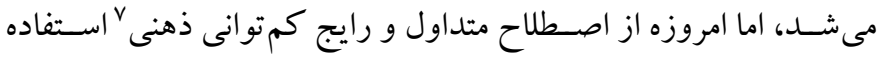

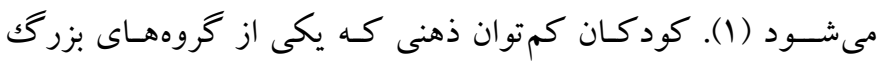

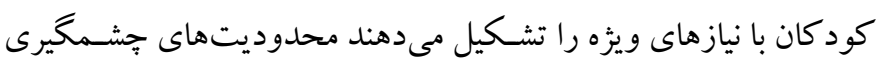

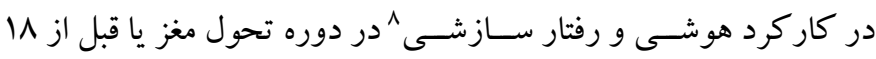

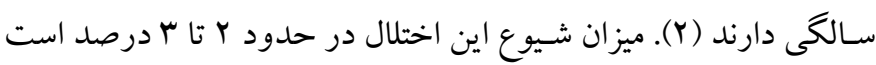

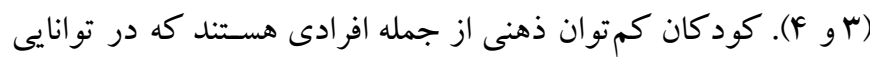

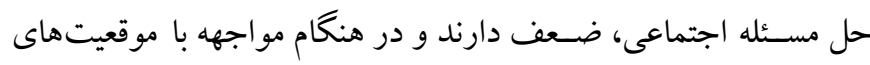

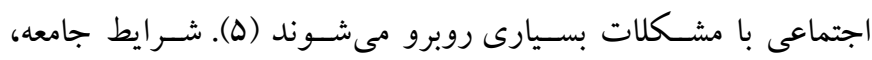

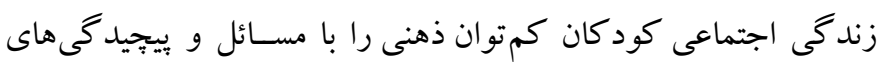

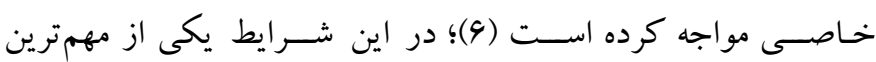

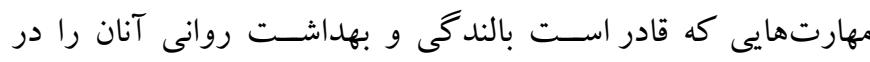

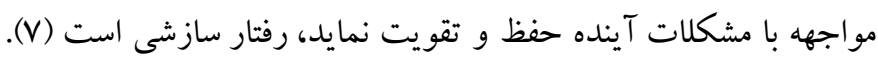

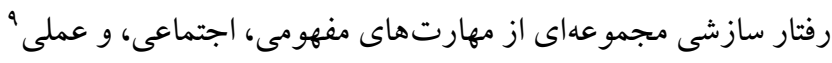

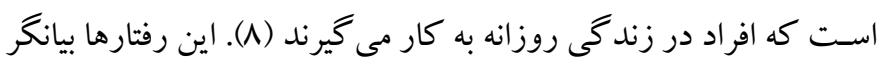

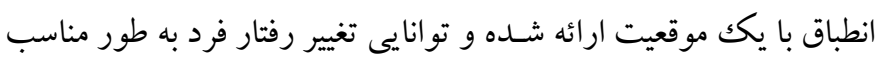

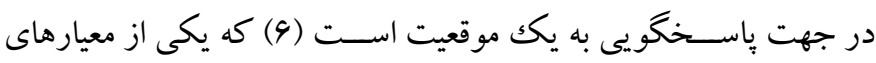

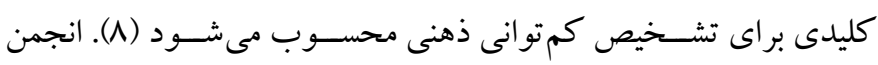

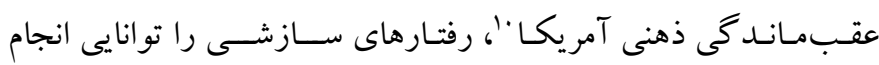

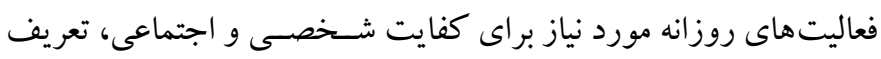

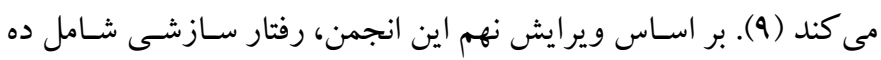

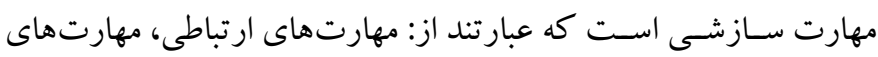

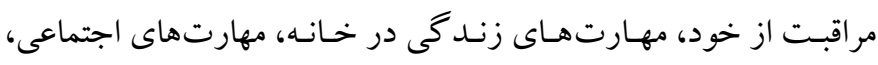

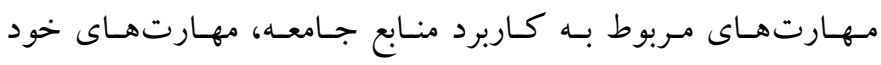

\section{Idiot}

2. Imbecile

3. Moron

4. Mental impairment

5. Intellectual deficiency

6. Mental retardation

7. Intellectual disability 
كم توان ذهنى مى توان بـه مطـالعات آقايىنزاد، فرامرزى و كريمى (YD)؛

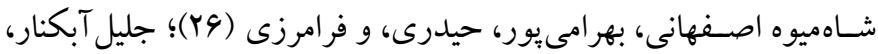

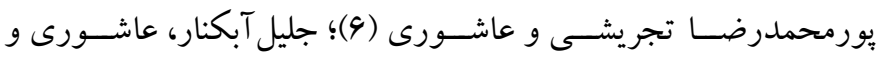

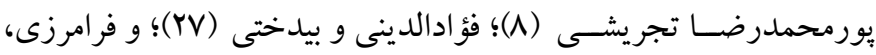
افروز و ملككيور (YN) اشاره كرد. با اينكه مداخلات مبتنى بر بازىدرمانى بر رفتار ســازشـى كود كود كان كم توان ذهنى تأثير مطلوبى داشته ولى ميزان تأثير آن از كم تا بسيار زياد باد باد

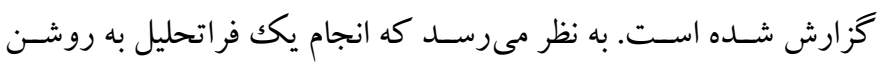
سـاختن مقدار واقعى اثربخشسى مداخلات مبتنى بر بازىدرمانى بر رفتار سـازشسى كود كان كمك خواهد كرد كه اين موضسوع حاكى از خلاء يزؤهشى در اين حوزه و اهميت و ضـرورت ئزوهش حاضـر اسـت. بايد

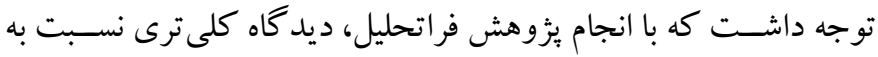

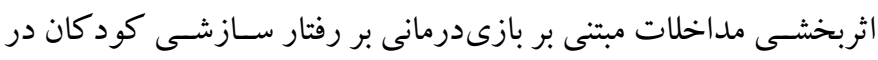

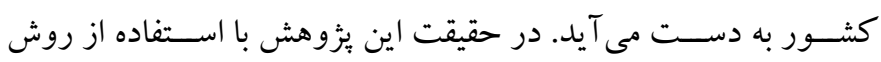

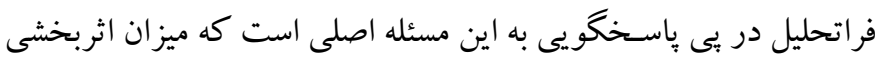

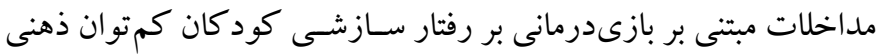

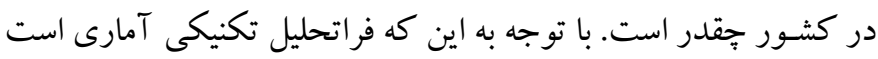

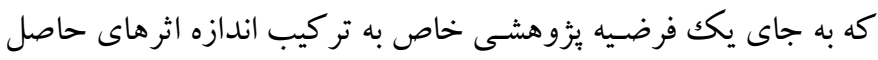

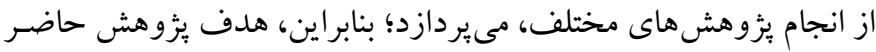

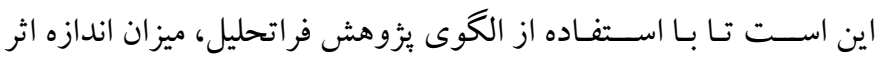

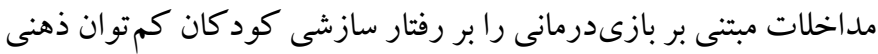

مشخص كند.

روش

الف) طرح هزوهش و شـــر كت كنند كان: يزوهش حاضـر با توجه به عنوان و ماهيت مطالعه از نوع فراتحليل استـ. اصـل اساسى در فراتحليل

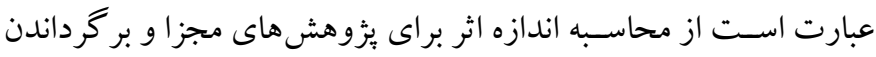

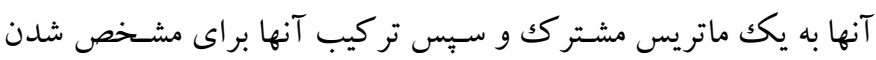

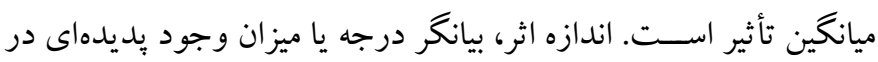

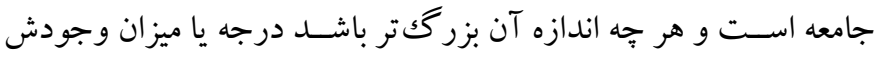
بيشتر اسـت. حجم اثر نيز مفهوم اصلى در فراتحليل است كه رابطه ميان

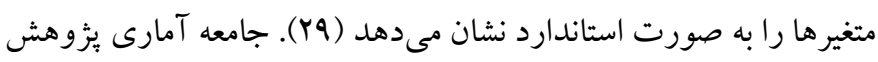

وى بـه كـار گرفتـه مى شــود و بـه كود كك كمـك مى كند تا فشــارها و احساسات خويش را مهار كند. در بازىدرمانى بر مشاركت كودك در

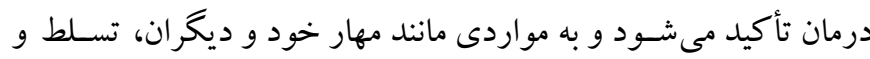

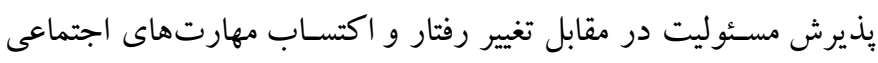
توجه مىشــود. در بازىدرمانى از روشهايى مانند خودنظارتى و فنون

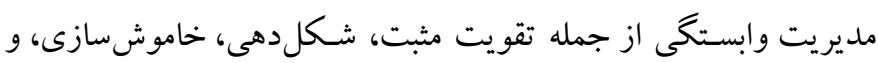
سـرشـقدهى استفاده مى شود كه با هدف بهبود مهارت هاى اجتماعى و

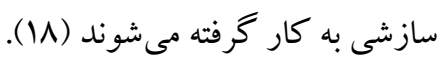

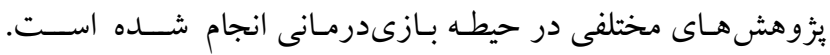

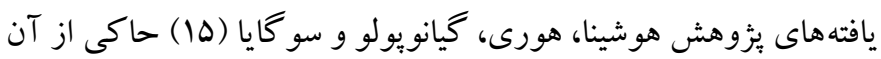

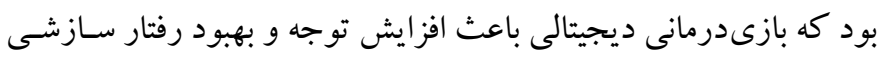

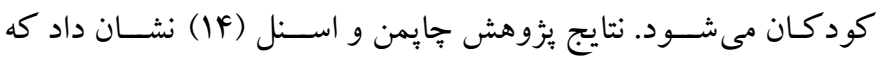

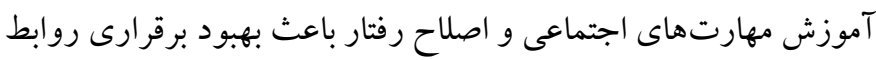

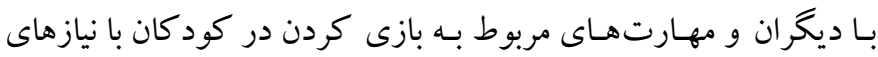

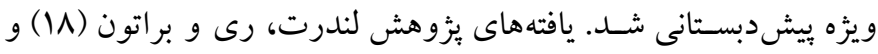

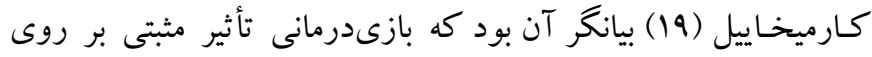

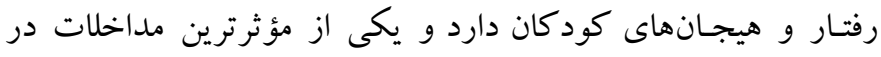

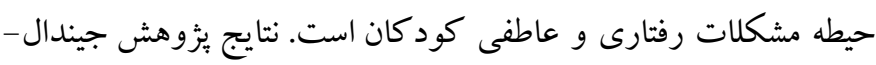

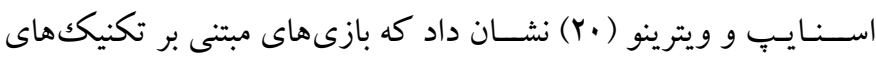

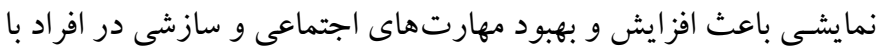

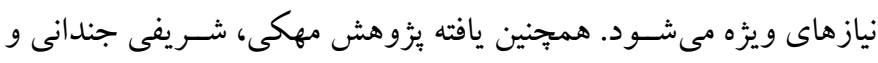

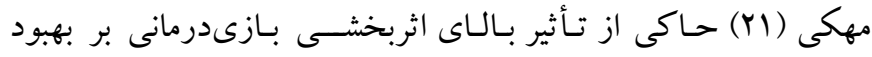

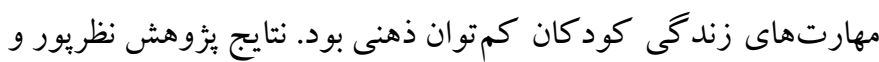

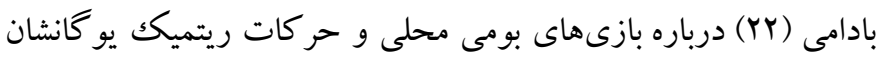

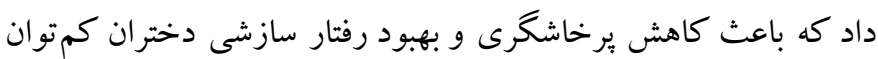

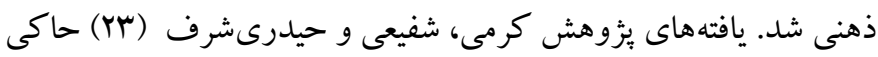

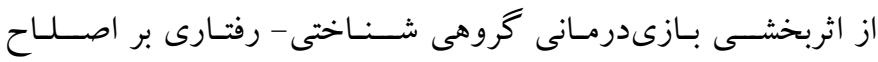

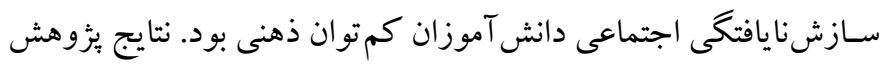

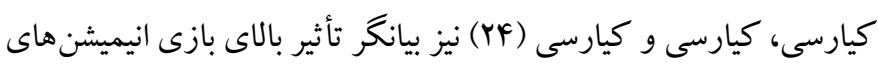

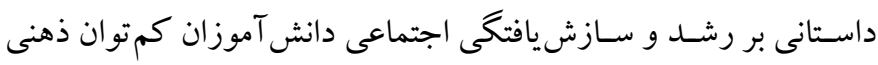

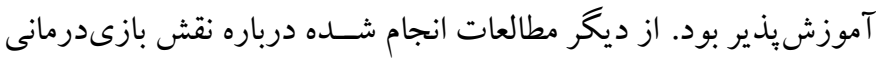

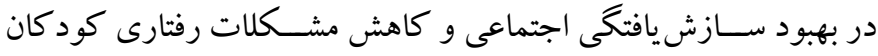


يُزوهش مورد سوال قرار گرفته است. در صورت واضح نبودن معيار هاى

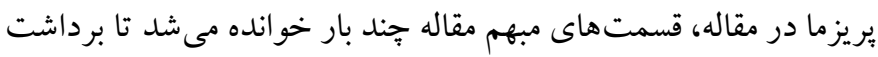

$$
\text { دقيقى حاصل شود. }
$$

ب) ابزار: براى جمع آورى اطلاعات از يكك فرم كد گذذارى يا فهرسـت

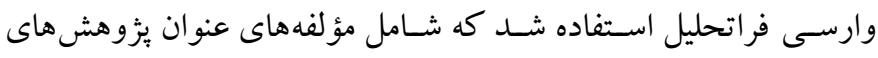
انجام شـده، مشـخصات يُزوهشگر ان، سال، محل اجرا، فرضيه ها، ابزارها، جامعه آمارى، حجم نمونه، و مقدار احتمال مى شــــ. ملاككهاى ورود به تهريه

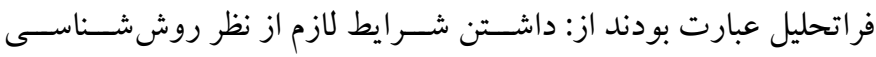

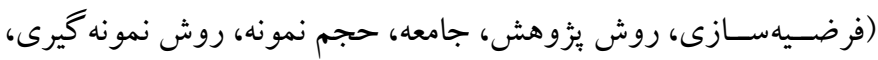

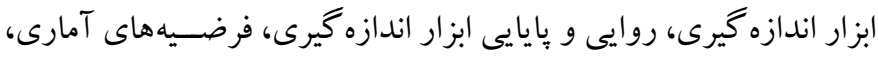

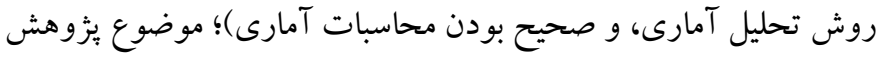

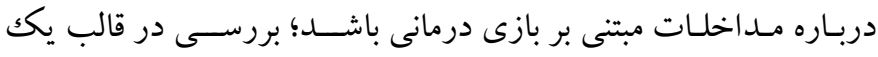

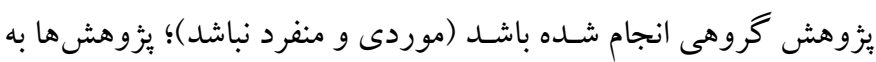

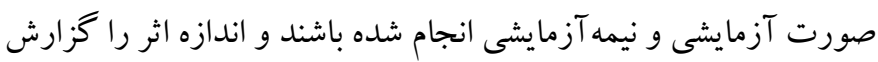

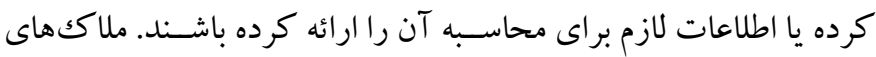

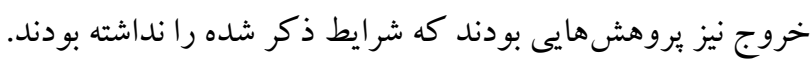

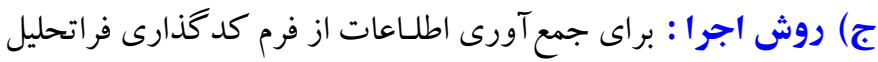

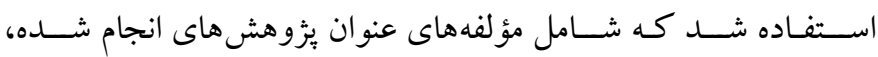

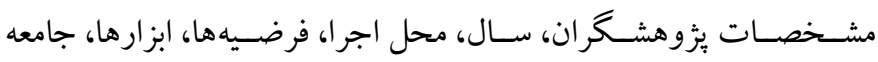
آمارى، حجم نمونه، و مقدار احتمال مى شد. مراحل اجر ایى اين فراتحليل

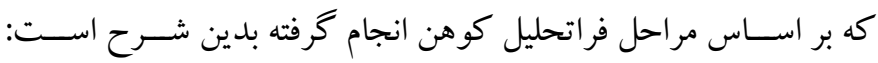

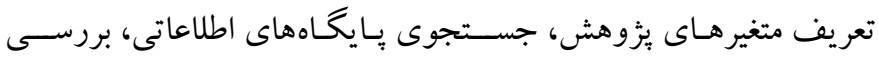

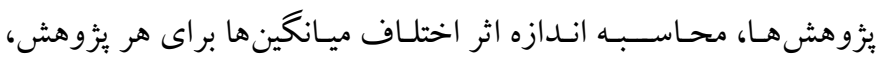

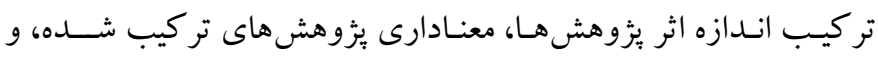

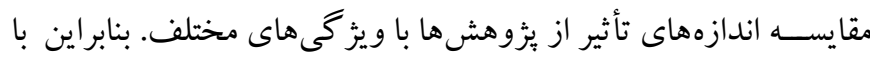

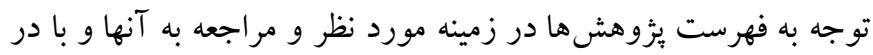

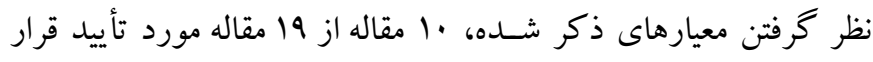

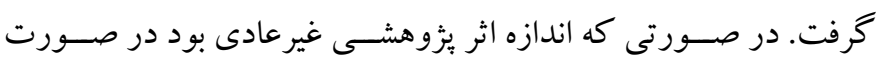

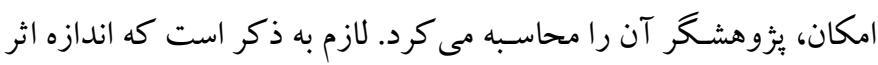

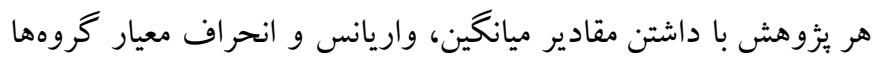

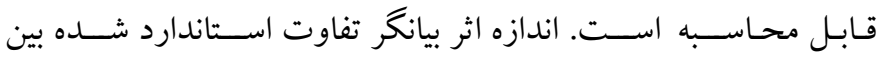
ميانگين هاى گروههاى آزمايش و گو اه اسـتـت و براى محاسـبه آن بايد
را مقاله هاى جاب شــده فارسسى در مجلات علمى يُزوهشى مورد تأييد

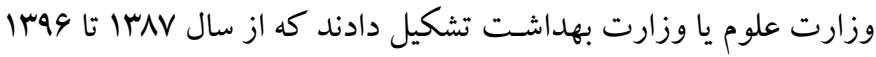

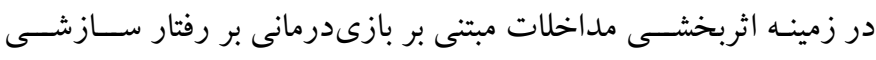

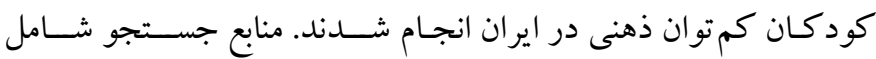

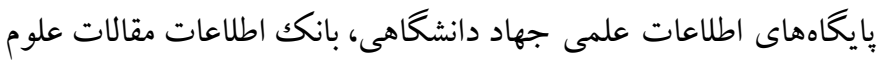

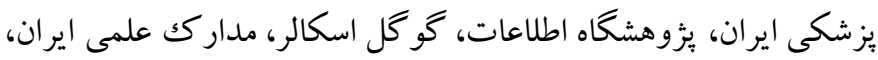

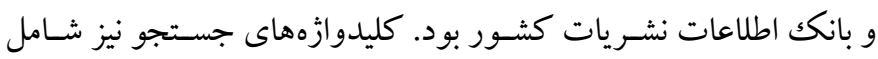
بازىدرمانى، رفتارهاى سـازشى و مشكلات رفتارى بود. به اين ترتيب 19

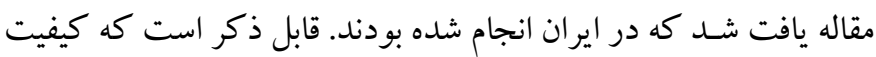

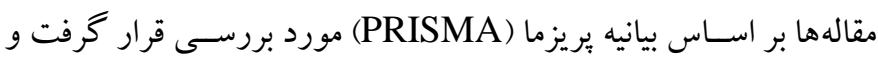

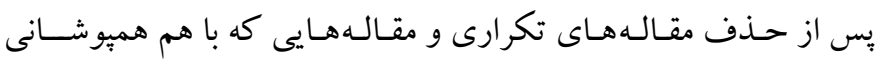

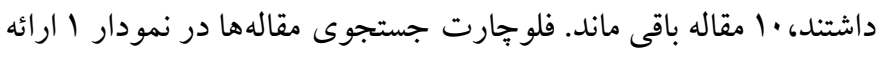
شله است.

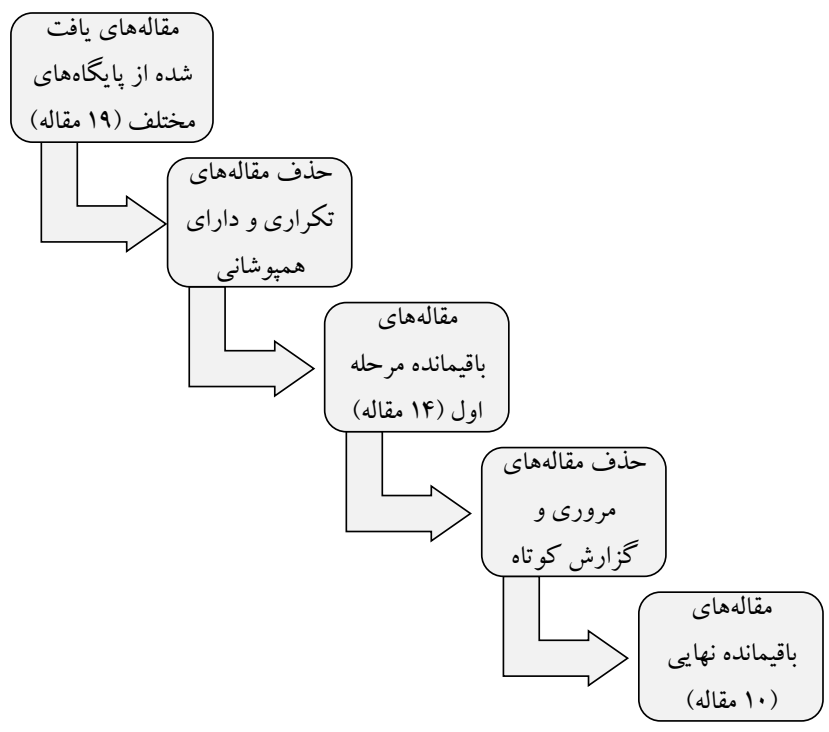

نمودار ا: فلوجارت جستجوى مقالهها

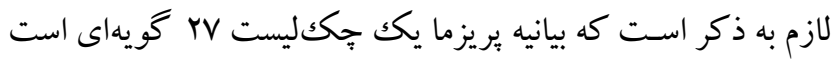

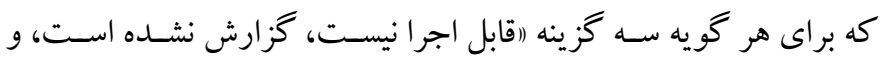

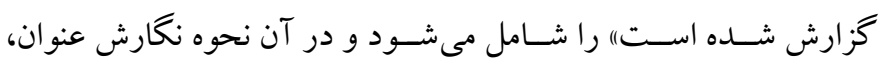

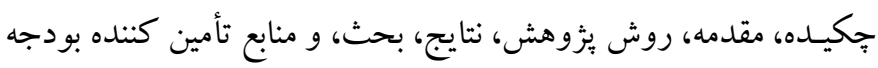


انجام اين فراتحليل از نسخه دوم نرمافزار جامع فراتحليل ' يا CMA-2 و

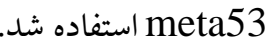

\section{يافتهها}

ويز گى هاى توصـيفى و نتايج يزوهش هايى مربوط به ميزان اثربخشـى مداخلات مبتنى بر بازىدرمانى بر رفتار سـازشى كود كان كمت توان ذهنى در جدول ا خزارش شده است.
نسبت تفاوت ميانخين نمرههاى گروههاى آزمايش و گواه را بر واريانس

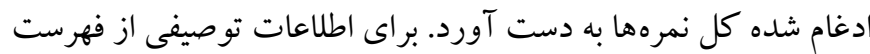

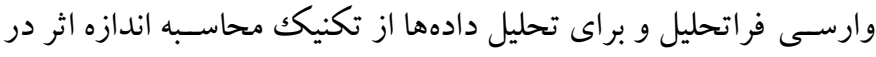

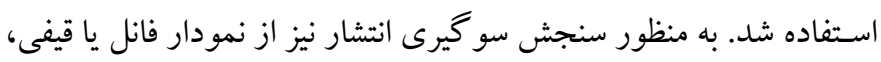
درباره ميزان اطمينان مورد انتظار از بر آورد تعداد ناكامل بىخطر، و و براى

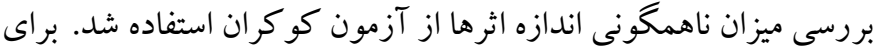

جدول ا: مشخصات بزوهشهاى مورد استفاده در فراتحليل اثربخشى مداخلات مبتنى بر بازىدرمانى بر رفتار سازشى

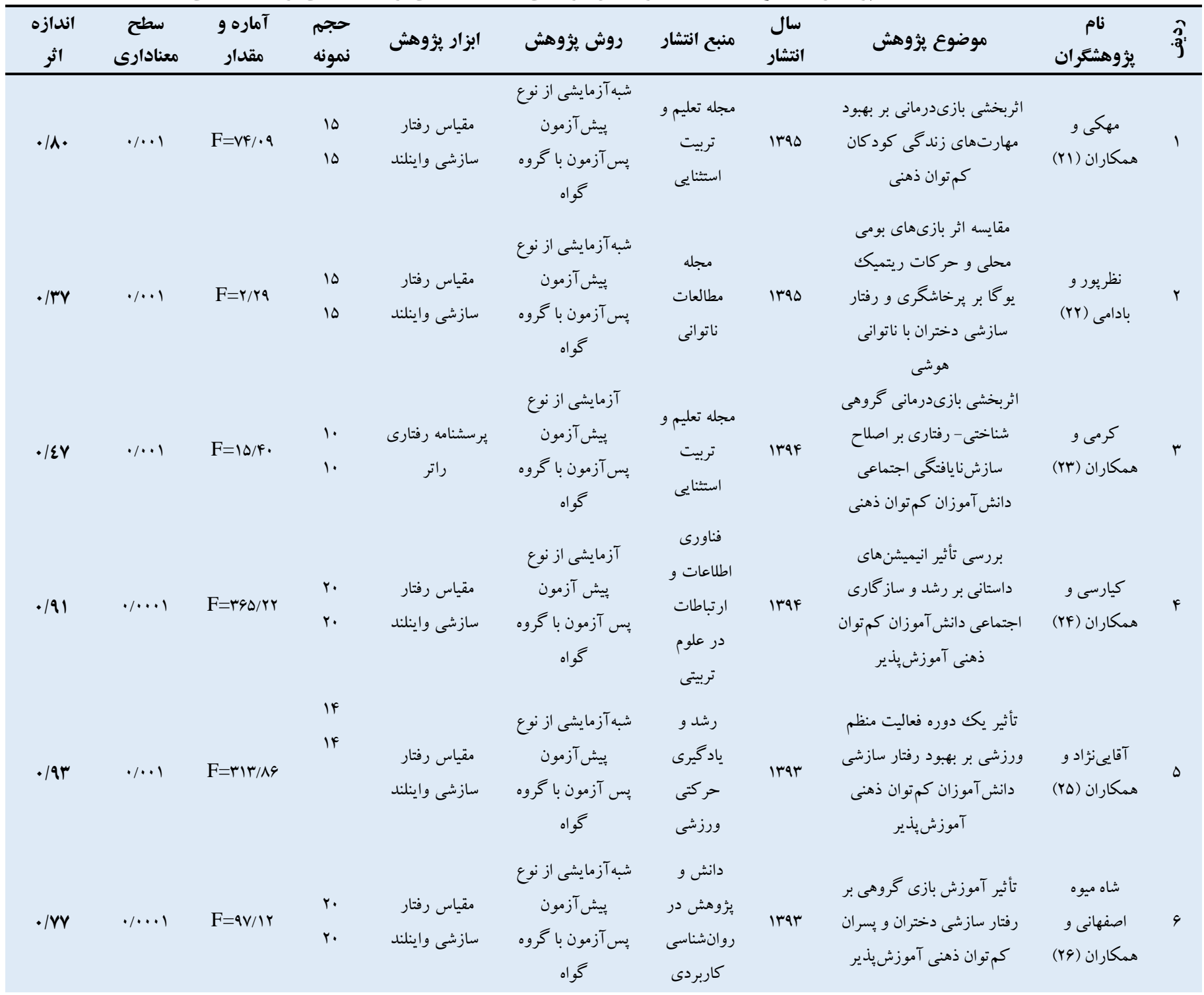




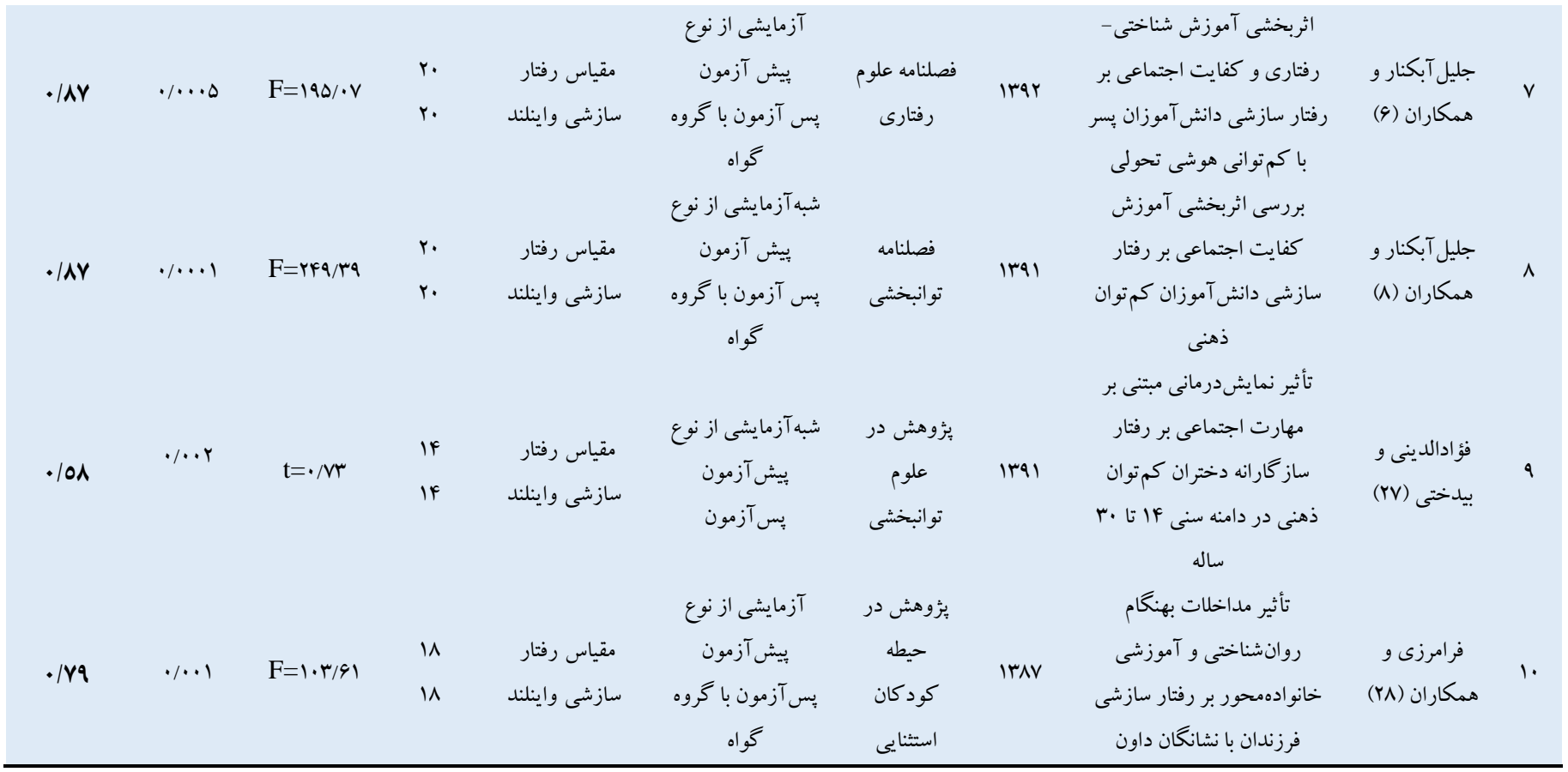

توجـه بـه نوع بزؤهش، روش نمونسه كيرى، ســن آزمودنى هـا، و ســاير

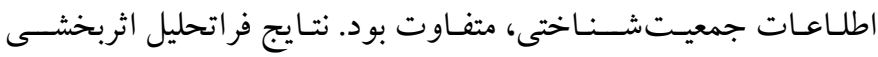
مداخلات مبتنى بر بازىدرمانى بر مهارت هاى اجتماعى كود كان كمتوان ذهنى در جدول Y گزارش شده است.
همانطور كه در جدول ا مشــاهده مىشـود شـاخص هاى اصـلى يثزوهش هـاى مورد اســتفـاده در فراتحليل اثربخشـى مداخلات مبتنى بر بازىدرمانى بر رفتار سـازشـى كود كان كمتوان ذهنى، گزارش شــده اســت. بـا توجـه بـه اين جـدول مى توان كفت در همه يزٔوهش ها فرض خلاف تأييد شــــ يعنى همه آنها اثربخش بودهاند، ولى اندازه اثر آنها با

جدول r: نتايج فراتحليل اثربخشى مداخلات مبتنى بر بازىدرمانى بر رفتار سازشى

\begin{tabular}{|c|c|c|c|c|c|c|c|}
\hline ميانكين اندازه اثر & تبديل z به سطح & تبديل r به & اندازه اثر كوهن & تبد z بل r & تبديل سطح معنادارى & سطح معنادارى & ئزوهش \\
\hline \multirow{10}{*}{.190} & \multirow{10}{*}{$\cdot \cdots \cdot \cdot$} & $.19 \pi \pi$ & $1 / \pi \Delta$ & .109 & $r / . q$. &.$/ \cdots 1$ & 1 \\
\hline & & . & 1/rם & .109 & $r / . q$. &.$/ .1$ & $r$ \\
\hline & & - /AFA & $1 / 91$ & .199 & $r / . q$. &.$/ .1$ & $r$ \\
\hline & & $.19 \mathrm{VA}$ & $1 / 49$ & $\cdot / \Delta 9$ & $r / v 19$ &.$/ \cdots 1$ & $\varepsilon$ \\
\hline & & . /Drq & $1 / 1 r$ & $\cdot / 49$ & $r / . q$. &.$/ \cdots 1$ & 0 \\
\hline & &.$/ 9 \mathrm{VA}$ & $1 / 49$ & $\cdot / 09$ & $r / v / q$ & $\cdot / \cdots$, & 7 \\
\hline & &.$/ 9 \mathrm{VA}$ & $1 / 49$ &.$/ 09$ & $r / v 19$ & $\cdot / \cdots \Delta$ & r \\
\hline & &.$/ 9 \mathrm{VA}$ & $1 / 44$ & $\cdot / \Delta 9$ & r/viq & $\cdot / \cdots$, & $\wedge$ \\
\hline & & - /Drq & $1 / 1 r$ & $\cdot / 4 q$ & $r / . q$. & $\% r$ & 9 \\
\hline & & $\cdot / \Delta V q$ & $1 / r Y$ & . $/ \Delta r$ & $r / . q$. &.$/ .1$ & 1. \\
\hline
\end{tabular}




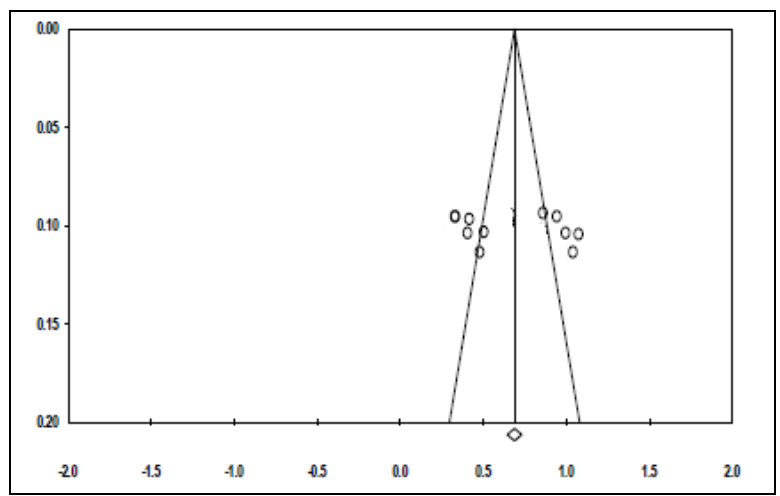

نمودار r: نمودار فانل (قيفى) خطاى معيار بر اساس z فيشر

با تو جه به نمودار Y مشــاهده مىشـود كه بثزوهش ها در بالاى نمودار جمع شـدهاند، خطاى استاندارد يايينى دارند و سو گيرى انتشار ندارند؛ به

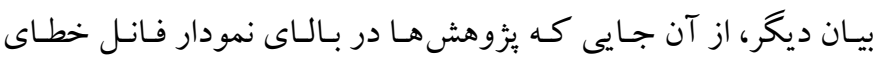

استاندارد بر اساس Z فيشر جمع شدهاند سو گيرى انتشار وجود ندارد. ميزان اطمينان مورد انتظار نيز از طريق بر آورد تعداد ناكامل بىخطر يا N ايمن از خطا' براى يزٔوهشهاى وارد فراتحليل شده محاسبه شد. منظور از تعداد ناكامل بى خطر همان تعداد يزوهشهاى فرضى انتشار نيافته و غيرمعنادارى است كه اكر به بثزوهش هاى تر كيب شده اضافه شود باعث عدم معنادارى كل ثيزوهش ها مىشود. تعداد ناكامل بى خطر در جدول r كزارش شده است.

\begin{tabular}{|c|c|c|c|c|}
\hline \multicolumn{5}{|c|}{ جدول "َ: بر آورد تعداد ناكامل بى خطر } \\
\hline تعداد & مقدار & مقدار z دحر انى & معنادارى سطح & 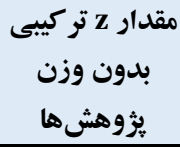 \\
\hline $1 V 91$ &.$/ . \Delta$ & $1 / 99$ & 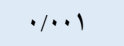 & 11/ror \\
\hline
\end{tabular}

بر اســاس نتايج جدول لا، تعداد ناكامل بىخطر براى اين فراتحليل، IV9人 بيزوهش انتشــار نيـافتـه اســـ؛ يعنى بايد به همين تعداد، بزوهش غير معنادار انتشـار نيافته وجود داشـته باشـــ تا در مجموع ميز ان اثربخشى مداخلات مبتنى بر بازىدرمانى بر مهارت هاى اجتماعى كود كان كمتوان ذهنى را غيرمعنـادار كند. از آن جايى كه اين تعداد يُوهش بســيار زياد
همانطور كه در جدول r مشـاهده مىشود بالاترين اندازه اثر مربوط

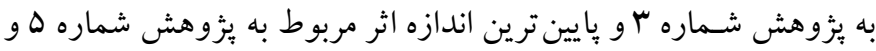
9 است. بر اساس نظر كوهن (1991)، براى شاخص r اندازههاى اثر / •،

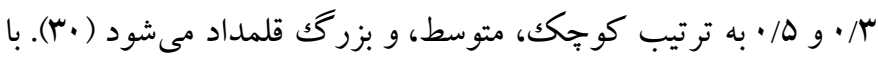
توجـه بـه اطلـاعـات اين جـدول، تأثير متغير مســتقل (مداخلات مبتنى بر بازىدرمانى) بر متغير وابسته (رفتار سـازشى)، 190 • به دست آمد كه بر اسـاس جدول تفسير اندازه اثر كوهن، بالاتر از متوسط ارزيابى مىشود و سطح معنادارى آن | |... • است؛ بنابر اين مى توان كفت طبق نتايج اين فراتحليـل، مـداخلات مبتنى بر بازىدرمانى بر رفتار ســازشـى كود كان كم تو ان ذهنى، اثر بالايى داشته است. يكى از موضـوعات مهم در هر فراتحليل، ارزيابى سـو گيرى انتشـار اسـت. منظور از سـو گيرى انتشار، اين است كه يكك فراتحليل شامل تمام يثزوهش هاى انجام شده در مورد موضوع مورد بررسى نيست. امكان دارد برخى بثزوهشها به علل مختلف، منتشـــر نشـــده باشـــد يا در مجلههاى نمايهسـازى شـدهف جاب نشـده باشند. زمانى كه سو گيرى انتشار وجود دارد، نتايج نهايى فراتحليل تحت تأثير قرار مى گيرد و بر آوردهاى نهايى حاصل از آن داراى تورش و خطا هستند. يس لازم است سو گيرى انتشار شـناسـايى و تصسحيح نشـود تا اعتبار نتايج افزايش يابد. به همين خاطر از نمودار فانل يا قيفى استفاده شد كه در آن اثر مداخله بر آورد شده از هر يثزوهش در مقـابل اندازه نمونه آن بثزوهش رســم مىشــود. اگر تورش انتشـار وجود نداشـته باشــ نمودار متقارن است و مقدار براكندكى حول اندازه اثر مداخله با افزايش نمونه كاهش مىيابد. يزؤهشهايى كه خطاى

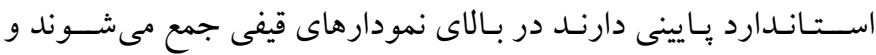
سـو گيرى انتشـار ندارند. هر جهه يُزوهش ها به سـمت يايين قيف كشـيده شـوند خطاى استاندارد بيشتر و سو گيرى انتشار افزايش مىيابد. نمودار ب نمودار فانل يا قيفى بثزوهش حاضـر اسـت كه جهت بررسـى سـو گيرى انتشار ارائه شده است.

1. Number fail safe 


\section{بحث و نتيجه كيرى}

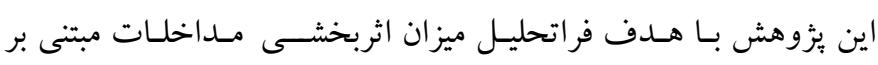
بازىدرمانى بر رفتار سازشى كود كان كم توان ذهنى انجام شد. فراتحليل

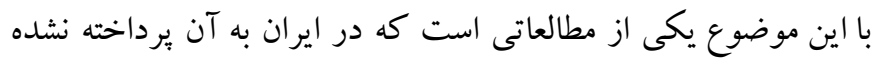
اسـت. يافته هاى حاصـل از اين فراتحليل نشــان داد كه ميزان اندازه اثر

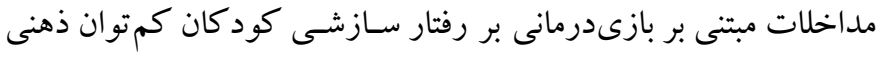

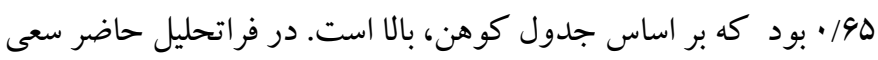

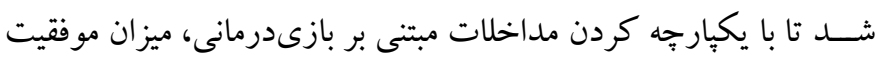

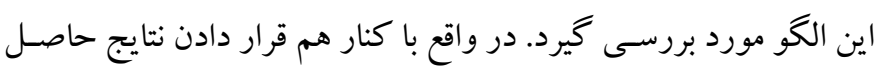

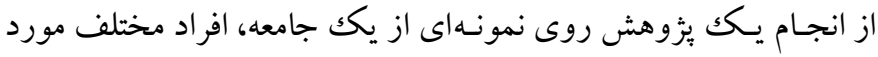

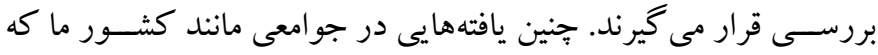

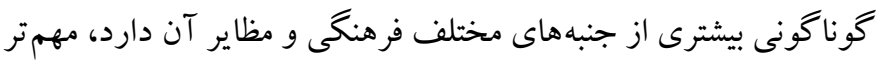

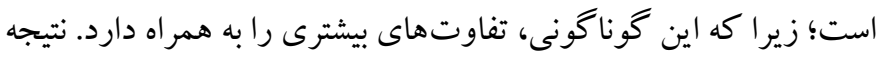

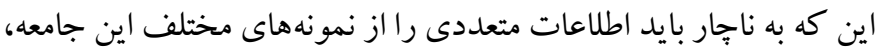
در دسـت داشـت تا با يكهيارجه كردن اطلاعات، شـباهتها را به دسـت

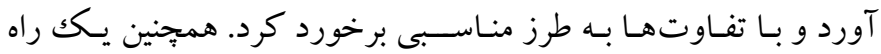

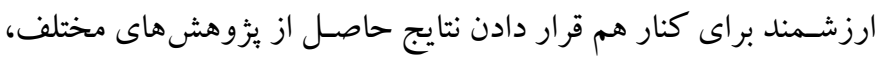

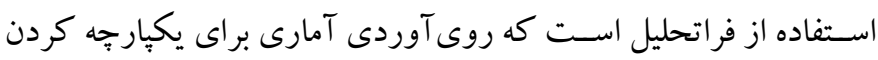

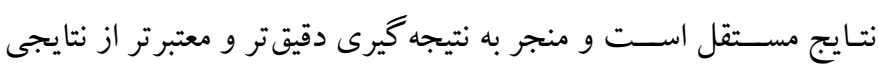
مىشـود كه از يكك مطالعه اوليه به دسـت مى آيد (اسب). از ديخر امتيازات جنين فراتحليل هايى اين اسـت كه جون شـكافهاى موجود بين بيشـــــ

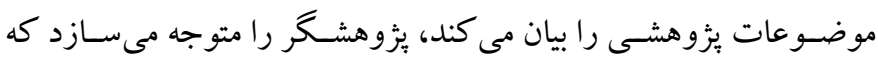

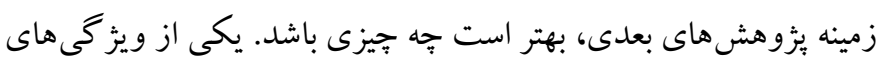

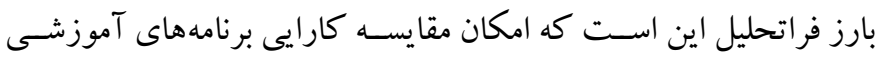

مختلف را در بافت هاى فرهنكى مختلف فراهم مى كند ( •r).

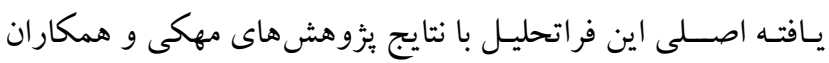

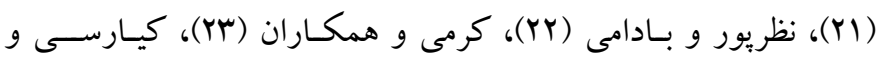

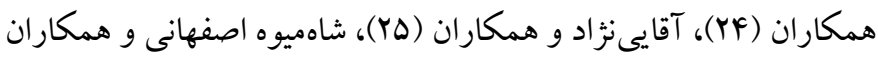

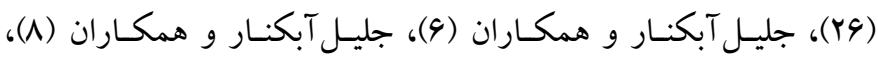
فؤادالدينى و بيدختى (YV)، و فرامرزى و همكاران (Y^) همسو است.
اسـت، بِ بعيد به نظر مىرسـد كه متغير مسـتقل يثزوهش حاضر بر متغير

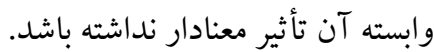
مسئله ديخر بررسى ميزان ناهمخًونى ' اندازه اثرها است كه با استفاده

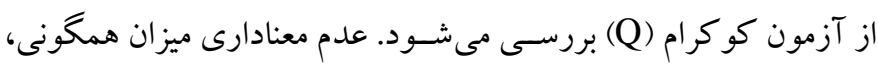

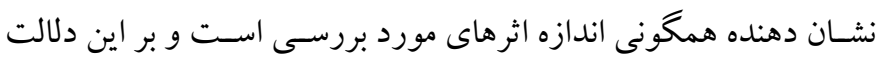

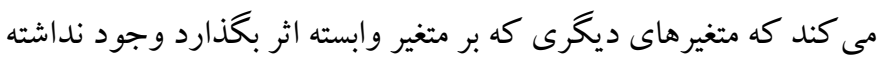

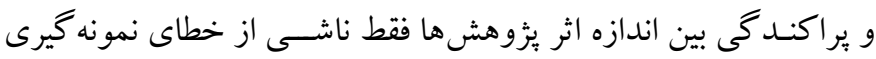

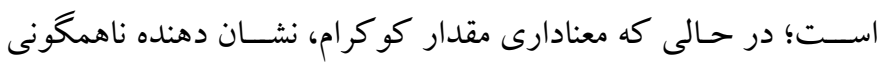

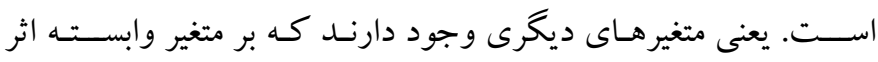

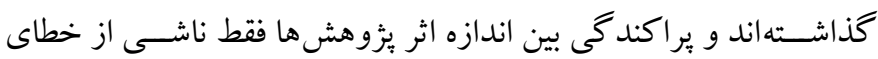

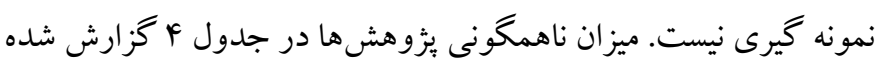

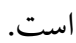

\begin{tabular}{|c|c|c|c|}
\hline تفسير & معنادارى سطح & آزادى درحه & Q مقدار Q \\
\hline معنادارى آزمون Q به معنى &.$/ \cdots 1$ & 9 & $11 \% / \Delta \cdot 9$ \\
\hline
\end{tabular}

با توجه به نتايج جدول Fا، مقدار شـاخص كو كرام، زياد اسـت و اين

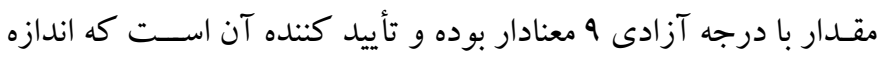
اثرها ناهمخون هستند؛ يعنى متغيرهاى ديخرى وجود داشتند كه بر متغير

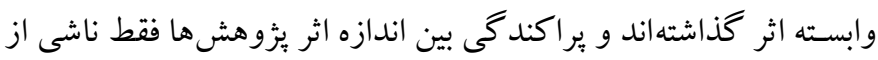

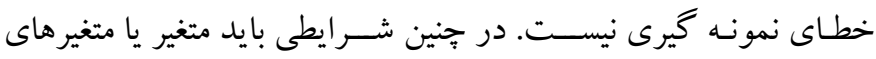
مداخله گر مورد بررسى قرار گيرند كه اين كار به وسيله طبقهبندى دئس دادهها

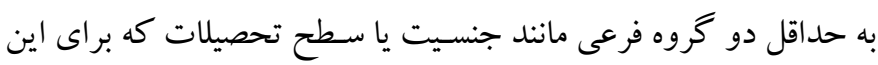

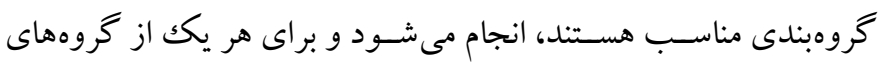

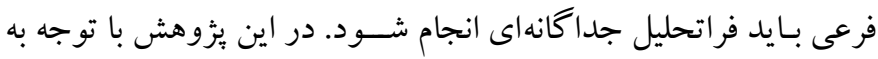

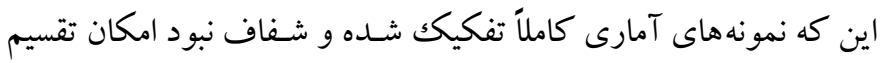

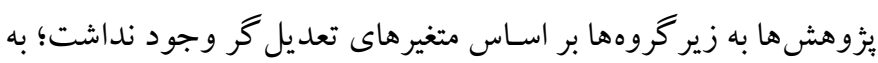

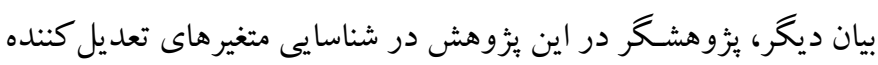
با محدوديت مواجه بود. 
آموزش بازىدرمانى به كودكان با نيازهاى ويزه، مورد توجه بسـيارى از

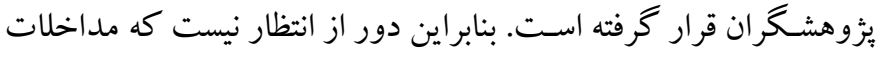

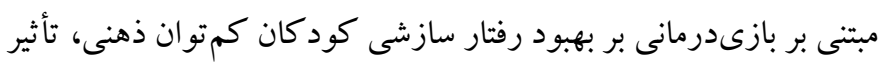

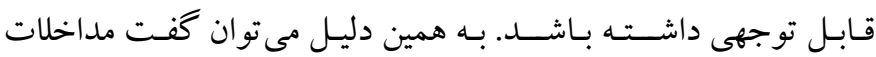

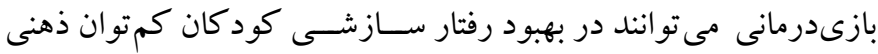
سهم عمدهاى داشـته باشـند و به عنوان روشى مناسـب براى بهبود رفتار سازشى اين كود كان در مكانهاى آموزشى و توانبخشى مختلف مانند

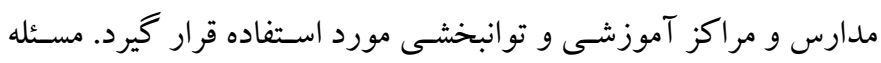

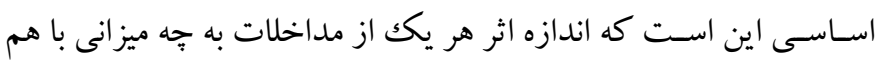
متفـاوت بودنـد، ميزان تأثير هر يكك جقدر اســت، و كدام يكك مؤثرتر

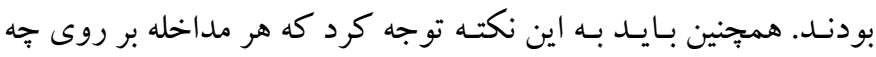

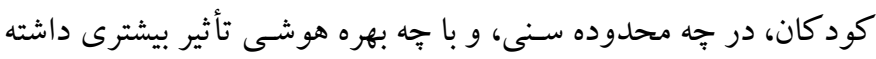

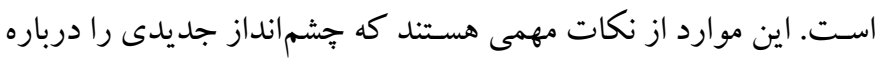
مداخلات مبتنى بر بازىدرمانى نمايان مى كنند.

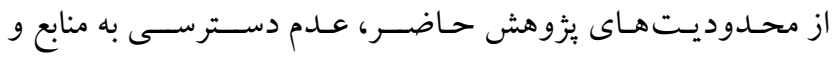

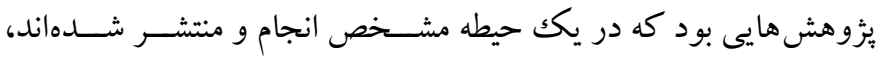

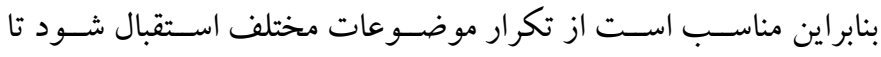

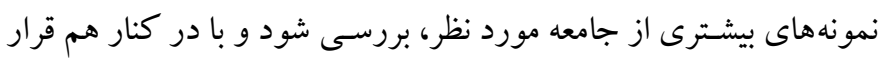
دادن نتايج حاصـل از نمونههاى مختلف، ديد بهترى نســبت به واقعيت

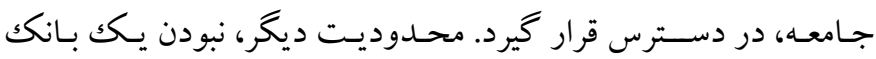
اطلاعاتى منسجم و منظم در كشور براى انجام جنين يزوهش هايى است.

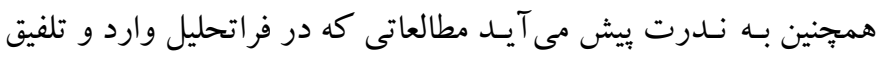

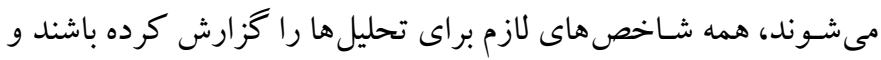
اين جزء محدوديتهاى اسـاسى در انجام فراتحليل اسـت. در اين رابطه يُشنهاد مى شود تمام شاخص هاى بثزوهشى از جمله روش بثزوهش، حجم نمونه، شـاخص هاى روانسـنجى ابزارهاى مورد اسـتفاده، روش تحليل

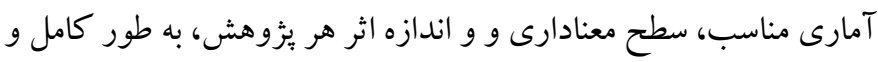

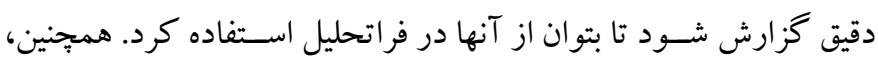

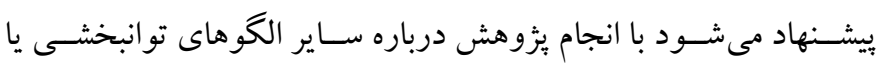

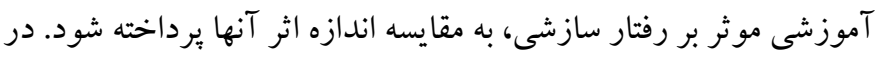
ضـمن مى توان يُزوهشى در همين حوزه در خارج از كشـور انجام دادو و نتايج اين دو بثزوهش را مقايسه كرد.
در راستاى تبيين اين يافته مىتوان كفت كود كان با نيازهاى خاص به

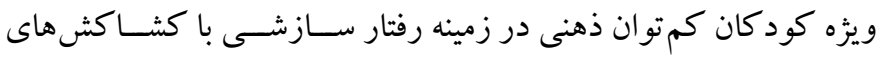

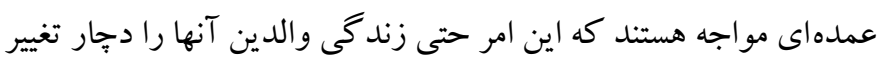
قابل توجهى مى كند (^). در حقيقت شـرايط نامناسبى كه فرزندان تجربه

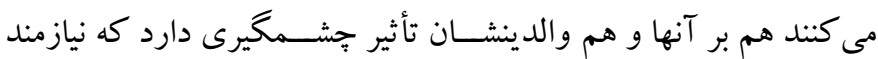

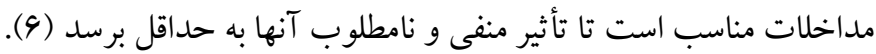
بازىدرمانى سـبب مى شود تا كود كان آكاهى بيشترى نسبت به رفتارها و

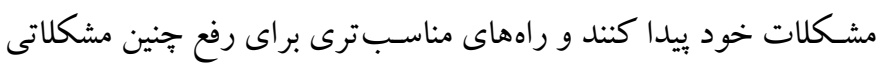

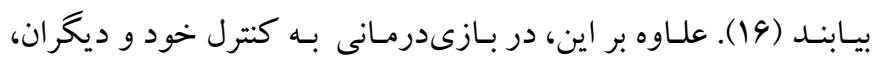
تسـلط و وذيرش مسسئوليت در مقابل تغيير رفتار، و اكتسـاب رفتارهاى

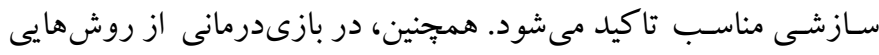

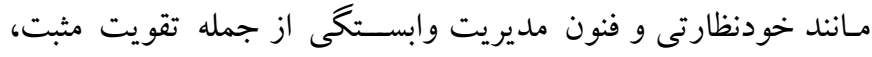

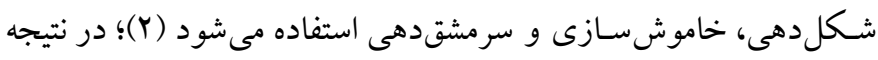

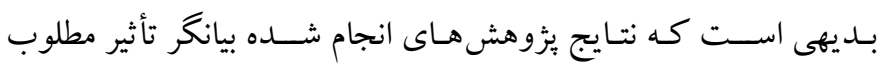

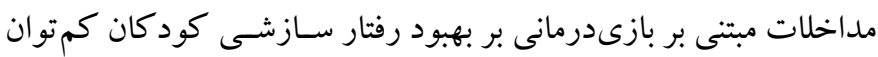

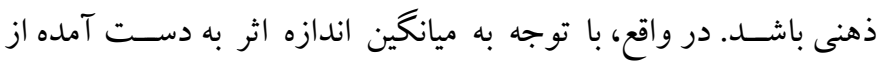

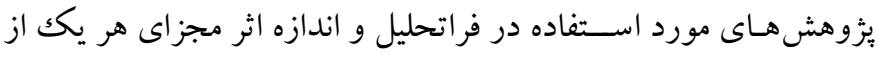

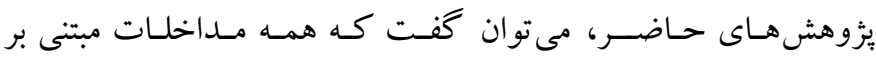

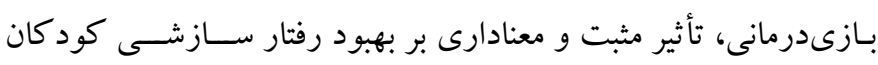
كم توان ذهنى داشتند. علاوه بر اين، درباره تببين يافتها و مقايسـه نتايج با ساير يزوهش هاى

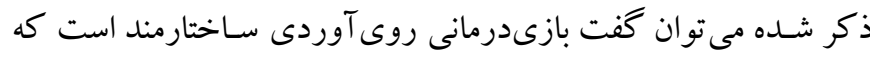

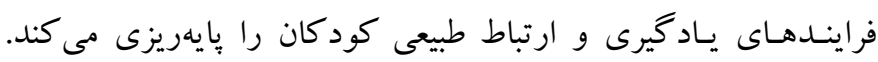

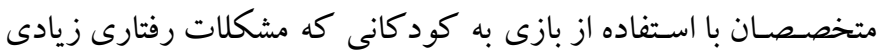

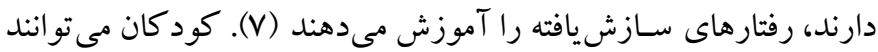

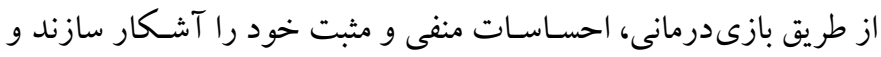

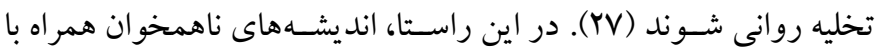
مشكلات رفتارى شـناسـايى و اصلاح مى شوند و در حقيقت تغييراتى در فرايندهاى شناختى كود كك به وجود مى آيد و بر بهبود رفتار سازشى ونى آنها

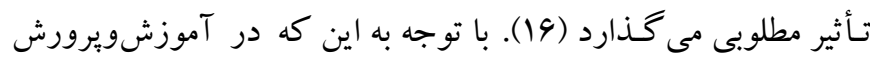
كود كان كم توان ذهنى، اكتساب مهارت هاى اجتماعى موضوع مهم و

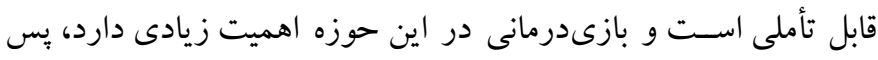


سـازشـى كود كان كم توان ذهنى در مر اكز آموزشسى و توانبخشى مورد استفاده قرار كيرند.

تشكر و قدردانى: اين مقاله بر گرفته از فعاليتهاى يزوهشى نو يسند كان است و به صـورت مسـتقل و بدون حمايت مالى هيج سـازمانى انجام شــــ همبجنين

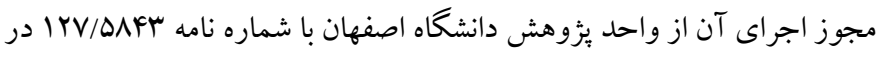

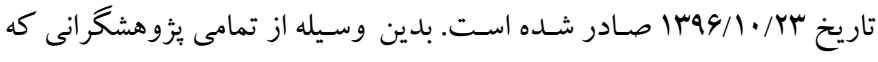
مقالههاى آنها در اين فراتحليل مورد استفاده قرار كرفته است، صميمانه تشكر و

$$
\text { قدردانى مى شود. }
$$

تضـاد منافع: در اين يثوهش هيج گونه تعارض منافعى توسط نويسـند كان كزارش نشده است.
در مجموع هدف يزوهش حاضـر اين بود كه با بررسى نتايج حاصل از اجراى يزوهشهـاى مختلف در كنـار هم، يـك نتيجـه كلى در مورد

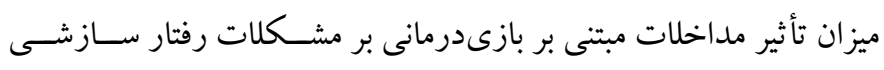

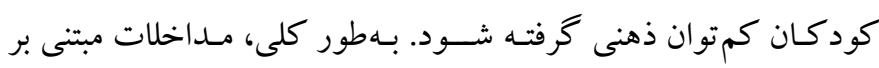
بـازىدرمسانى براى كمكك به كود كان و دانش آموزان كمتوان ذهنى و والدين آنها بسيار مفيد خواهد بود. يافته باى بثزوهش حاضر نيز نشان داد كـه ميزان اندازه اثر مداخلات مبتنى بر بازىدرمانى بر رفتار ســازشـى كودكـان كمتوان ذهنى بـالا بود؛ به بيان ديخر، نتايج اين فراتحليل از تأثير مداخلات مبتنى بر بازىدرمانى بر رفتار سـازشـى كود كان كمتوان

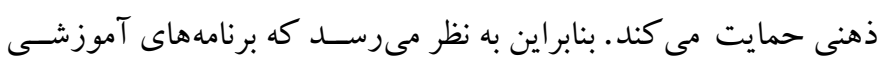
مبتنى بر بازىدرمانى مى توانند به عنوان روشسى مناسـب براى بهبود رفتار 


\section{References}

1. Ashori M, Jalil-Abkenar SS, Razavi F. Definition developmental intelligent disability and its different in diagnostic and statistical manual of mental disorders, 4th and 5th revision. Exceptional Education. 2015; 8(136): 57-60. [Persian]. [Link]

2. Hallahan DP, Kauffman JM, Pullen PC. Exceptional learners: An introduction to special education. $13^{\text {th }}$ edition. New Jersey: Pearson Education; 2015, pp: 8788. [Link]

3. Bakker-van Gijssel EJ, Lucassen PLBJ, Olde Hartman TC, van Son L, Assendelft WJJ, van Schrojenstein Lantman-de Valk HMJ. Health assessment instruments for people with intellectual disabilitiesA systematic review. Res Dev Disabil. 2017; 64: 1224. [Link]

4. Pourmohammadreza-Tajrishi M, Ashori M, Afrouz GA, Arjmandnia AA, Ghobari-Bonab B. The effectiveness of positive parenting program (triple-p) training on interaction of mother-child with intellectual disability. Archives of Rehabilitation. 2015; 16(2): 128-137. [Persian]. [Link]

5. Shamsi M, Hemmati Alamdarloo G, Shojaee S. Comparison of social problem solving ability in girl students with intellectual disability and normally developing peers. Quarterly Journal of Child Mental Health. 2018; 5(1): 15-24. [Persian]. [Link]

6. Jalil-Abkenar S, Pourmohamadreza-Tajrishi M, Ashori M. A comparison of the effectiveness of the cognitivebehavioral and social competency training methods on adaptive behavior of intellectually disabled boy students. Journal of Behavioral Sciences. 2013; 7(3): 189-197. [Persian]. [Link]

7. Kirk S, Gallagher JJ, Coleman MR. Educating exceptional children. 14th edition. Stamford, CT: Cengage Learning; 2014, pp: 4-7. [Link]

8. Jalil-Abkenar SS, Ashori M, PourmohammadrezaTajrishi M. Investigation of the effectiveness social competence instruction on the adaptation behavior in boy students with intellectual disability. Archives of Rehabilitation. 2013; 13: 104-113. [Persian]. [Link]

9. Luckasson R, Borthwick-Duffy S, Buntinx WHE, Coulter DL, Craig EM, Reeve A, et al. Mental retardation: Definition, classification, and systems of supports. 10th Edition. American Association on Mental Retardation, 444 North Capitol St; 2002, pp: 200-201. [Link]

10. Raines JC. Improving the self-esteem and social skills of students with learning disabilities. Encyclopedia of Social Work; 2016, pp: 1-19. [Link]
11. O’Handley RD, Ford WB, Radley KC, Helbig KA, Wimberly JK. Social skills training for adolescents with intellectual disabilities: A school-based evaluation. Behav Modif. 2016; 40(4): 541-567. [Link]

12. Drossinou-Korea M, Panopoulos N. Strengthening social skills in students with an intellectual disability in secondary education. Sino-US English Teaching. 2017; 14(6): 345-359. [Link]

13. Ashori M, Norouzi G, Jalil-Abkenar SS. The effect of positive parenting program on mental health in mothers of children with intellectual disability. J Intellect Disabil. 2019; 23(3): 385-396. [Link]

14. Chapman T, Snell M. Promoting turn-taking skills in preschool children with disabilities: The effects of a peer-based social communication intervention. Early Children Research Q. 2011; 26: 303-19. [Link]

15. Hoshina A, Horie R, Giannopulu I, Sugaya M. Measurement of the effect of digital play therapy using biological information. Procedia Comput Sci. 2017; 112: 1570-1579. [Link]

16. Ashori M, Dallalzadeh Bidgoli F. The effectiveness of play therapy based on cognitive-behavioral model: behavioral problems and social skills of pre-school children with attention deficit hyperactivity disorder. Archives of Rehabilitation. 2018; 19(2): 102-115. [Persian]. [Link]

17. HosseinKhanzadeh AA. The effect of child-centered play therapy on the self-efficacy in peer relations among students with oppositional defiant disorder symptoms. Quarterly Journal of Child Mental Health. 2017; 4(3): 49-59. [Persian]. [Link]

18. Landreth GL, Ray DC, Bratton SC. Play therapy in elementary schools. Psychol Sch. 2009; 46(3): 281289. [Link]

19. Carmichael KD. Play therapy: An introduction. Upper Saddle River, N.J: Pearson; 2005, pp: 124-127. [Link]

20. Jindal-Snape D, Vettraino E. Drama techniques for the enhancement of social-emotional development in people with special needs: Review of research. Int $\mathbf{J}$ Spec Educ. 2007; 22(1): 107-117. [Link]

21. Mahaki F, Shrifi Jondani H, Mahaki V. Effectiveness of play therapy on life skills of children with intellectual disability. Exceptional Education Journal. 2016; 2(139): 23-29. [Persian]. [Link]

22. Nazarpour E, Badami R. A comparative study of the effect of local indigenous games and rhythmic movements of yoga on aggressive and adaptive behavior in girls with intellectual disability. Middle Eastern Journal of Disability Studies. 2016; 6: 251256. [Persian]. [Link] 
23. Karami J, Shafeei B, Heidarisharaf P. Effectiveness of cognitive-behavioral play therapy on reforming the social maladjustment of female students with intellectual disabilities. Exceptional Education Journal. 2015; 3(131): 21-30. [Persian]. [Link]

24. Kiarasi Z, Kiarasi S, Kiarasi A. The effect of story animations on social development and adjustment on educable mentally retarded students. Information and Communication Technology in Educational Sciences. 2016; 6(4(24)): 91-110. [Persian]. [Link]

25. Aghayinejad J, Faramarzi S, Karimi M. The effect of a period of regular exercise activity on the improvement of adaptive behavior in educable mentally retarded students. Journal of Development and Motor Learning. 2015; 6(4): 511-529. [Persian]. [Link]

26. Shahmive Isfahani A, Bahramipour M, Heidari T, Faramarzi S. The effect of group play training on adaptive behavior of girls and boys with educable mental disabilities. Knowledge \& Research in Applied Psychology. 2015; 15(57); 64-71. [Persian]. [Link]
27. Foadodini M, Beydokhti H. The effect of drama therapy base on social skill adjusting behavior of mental retarded girls (IQ=55-70, 14-30 years old). Journal of Research in Rehabilitation Sciences. 2012; 8(5): 913-918. [Persian]. [Link]

28. Faramarzi S, Afrooz G, Malekpour M. The impact of early family-centered psychological and educational interventions on adaptive behaviors in children with Down syndrome. Journal of Exceptional Children. 2008; 8(3): 257-270. [Persian]. [Link]

29. Aghababaei S, Abedi A, Yarmohamadian A, ZamaniForoshani N. Meta-analysis of the effectiveness of applied behavioral analysis intervention on language skills in autism children. Journal of Clinical Psychology. 2015; 7(2): 77-86. [Persian]. [Link]

30. Rosenthal R, DiMatteo MR. Meta-analysis: Recent developments in quantitative methods for literature reviews. Annu Rev Psychol. 2001; 52: 59-82. [Link]

31. Martins A, Ramalho N, Morin E. A comprehensive meta-analysis of the relationship between emotional intelligence and health. Pers Individ Dif. 2010; 49(6): 554-564. [Link] 